\title{
Interplay of riparian forest and groundwater in the hillslope hydrology of Sudanian West Africa (northern Benin)
}

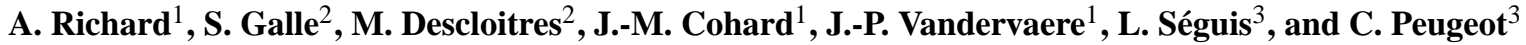 \\ ${ }^{1}$ UJF-Grenoble 1, LTHE, UMR5564, CNRS - UJF-Grenoble 1/G-INP/IRD, 38041 Grenoble, France \\ ${ }^{2}$ IRD, LTHE, UMR5564, CNRS - UJF-Grenoble 1/G-INP/IRD, 38041 Grenoble, France \\ ${ }^{3}$ IRD, HSM, UMR5569, CNRS - UM1/UM2), 34095 Montpellier, France
}

Correspondence to: A. Richard (alois.richard@ujf-grenoble.fr)

Received: 23 March 2013 - Published in Hydrol. Earth Syst. Sci. Discuss.: 2 May 2013

Revised: 22 October 2013 - Accepted: 25 October 2013 - Published: 13 December 2013

\begin{abstract}
Forests are thought to play an important role in the regional dynamics of the West African monsoon, through their capacity to extract water from a permanent and deep groundwater table to the atmosphere even during the dry season. It should be the case for riparian forests too, as these streambank forests are key landscape elements in Sudanian West Africa. The interplay of riparian forest and groundwater in the local hydrodynamics was investigated, by quantifying their contribution to the water balance. Field observations from a comprehensively instrumented hillslope in northern Benin were used. Particular attention was paid to measurements of actual evapotranspiration, soil water and deep groundwater levels. A vertical 2-D hydrological modelling approach using the Hydrus software was used as a testing tool to understand the interactions between the riparian area and the groundwater. The model was calibrated and evaluated using a multi-criteria approach (reference simulation). A virtual experiment, including three other simulations, was designed (no forest, no groundwater, neither forest nor groundwater).

The model correctly simulated the hydrodynamics of the hillslope regarding vadose zone dynamics, deep groundwater fluctuation and actual evapotranspiration dynamics. The virtual experiment showed that the riparian forest transpiration depleted the deep groundwater table level and disconnected it from the river, which is consistent with the observations. The riparian forest and the deep groundwater table actually form an interacting transpiration system: the high transpiration rate in the riparian area was shown to be due to the existence of the water table, supplied by downslope lateral water flows within the hillslope soil layer. The simulated ri-
\end{abstract}

parian transpiration rate was practically steady all year long, around $7.6 \mathrm{~mm} \mathrm{~d}^{-1}$. This rate lies within high-end values of similar study results. The riparian forest as simulated here contributes to $37 \%$ of the annual hillslope transpiration, and reaches $57 \%$ in the dry season, whereas it only covers $5 \%$ of the hillslope area.

\section{Introduction}

The West African climate is characterised by strong interactions between the atmosphere and the land surfaces (Koster et al., 2004). Moisture availability in the regions located around $10^{\circ} \mathrm{N}$ was found to be pivotal for the West African monsoon (WAM) dynamics (Lebel and Ali, 2009). It is suspected that the reservoir of continental groundwater (permanent unconfined groundwater) plays a major role in the WAM onset into the Sahel (Fontaine et al., 1999; Philippon and Fontaine, 2002). Abundant vegetation at this latitude, especially the trees of evergreen forests, potentially provides humidity to the atmosphere even during the dry season. From a hydrological point of view, it must be acknowledged that little is known about the interactions between vertical water transfer processes and streamflow generation processes. Former studies in Sudanian climate regions showed a significant proportion of the streamflow of headwater catchments generated by interflow (Lafforgue, 1982; Chevallier and Planchon, 1993; Masiyandima et al., 2003; Giertz and Diekkrüger, 2003). More recently a series of hydrodynamic, geochemical and subsurface geophysical investigations (Kamagaté et al., 2007; Séguis et al., 2011b) have shown the contribution of 
deep ground water to be negligible at the intermediate scale of the Donga catchment (Benin, $586 \mathrm{~km}^{2}$ ), leaving open the possibility that the permanent water tables participate in the water cycle only at the regional scale.

Applying the above knowledge in models produced inconsistent results. For one, by taking into account hillslope processes (overland flow and interflow) in an enhanced 1-D SoilVegetation-Atmosphere Transfer (SVAT) model, Giertz et al. (2006) correctly simulated the streamflow of the $16.5 \mathrm{~km}^{2}$ Aguima catchment (Benin). In the same area, but on a larger scale, Le Lay et al. (2008) used a TopModel approach (Beven and Kirkby, 1979) based on shallow hydrological processes to simulate discharges. A deep percolation term, not originally present in the model, was introduced to correctly simulate the discharge at the outlet of the Donga catchment. The introduction of the deep percolation flux remains questionable since no measurements were available. A recent review by Peugeot et al. (2011) shows that the hydrological and SVAT models used to compute the mesoscale water cycle over the Ouémé catchment agreed on streamflow simulation but that at the same time they differed significantly in evapotranspiration and water storage terms.

Since actual evapotranspiration measured at the local scale $\left(1 \mathrm{~km}^{2}\right)$ may represent up to $80-90 \%$ of the annual rainfall in northern Benin (Guyot et al., 2009), it certainly represents one of these key diagnostic variables. During the wet season, taking into account only the water stored in the first meter of soil, is not sufficient to explain the measured actual evapotranspiration (Guyot et al., 2009); during the dry season, the non-zero actual evapotranspiration is probably due to the persisting vegetation activity (Guyot et al., 2012; Mamadou et al., 2013). In the Brazilian Amazonia context, Nepstad et al. (1994) demonstrated that important hydrological processes in this area involve deep water storages. Green canopies during the dry season are partly explained by deep root systems. Markewitz et al. (2010) corroborated the previous results performing a one-dimensional vertical model. These authors noted that ignoring the deep hydrological processes could produce biased evapotranspiration estimations in global circulation models.

Knowing that riparian forests are a key element of the landscape in northern Benin (Natta et al., 2002), this paper addresses the interplay between riparian forests and the underlying groundwater and its impacts on the hydrological processes, which control the local and mesoscale water cycle. Numerous studies have demonstrated that riparian forests use a part of the groundwater flow that, ultimately, feeds the streamflow, thus riparian forests decrease the water yield of the basin (e.g. Dunford and Fletcher, 1947). Trees within the riparian zone generally use more water than similar trees over the rest of the catchment (Dye and Poulter, 1995; Scott, 1999). White (1932), Gribovszki et al. (2008) among many others used the daily fluctuations of the groundwater table to estimate the riparian transpiration. The interactions between riparian water use and groundwater level fluctuations have

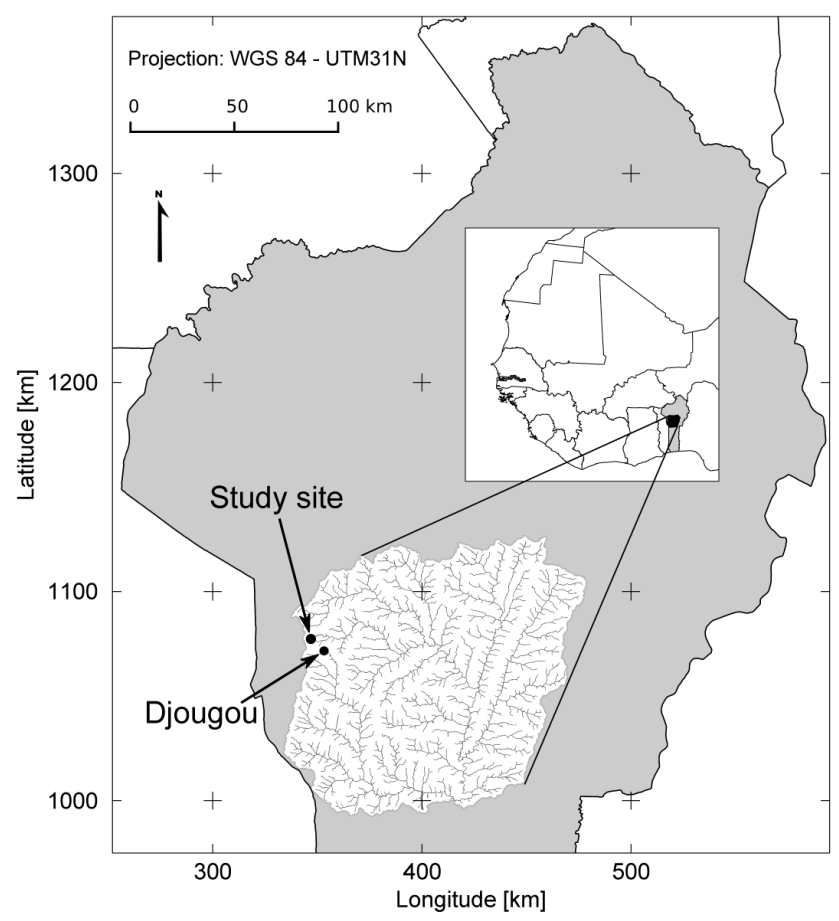

Fig. 1. Location of the study site. The watershed is the Sudanian climate mesoscale site of the AMMA-CATCH observing system, northern Benin, West Africa. Republic of Benin is the grey area.

been simulated (see e.g. Loheide II et al., 2005) or qualitatively characterized (Butler et al., 2007).

The African Monsoon Multidisciplinary Analysis - Coupling the Tropical Atmosphere and the Hydrological Cycle (AMMA-CATCH) observation system (Lebel et al., 2009) and its Sudanian site of the Ouémé catchment located in northern Benin (Fig. 1) provided an unprecedented set of data to explore the interaction between riparian vegetation and the water cycle. The study focused on the Nalohou hillslope (Fig. 2), a well-instrumented, elementary hydrological system. It includes a comprehensive set of measurements of the water budget terms. Particular attention was paid to the water distribution within the hillslope and its impact on evapotranspiration and water storage. The physically based Hydrus model (Simunek et al., 2006) was used as a coherent framework to represent and quantify the soil-water transfers in both lateral (water distribution at the hillslope scale) and vertical (transpiration) directions. A virtual experiment (Weiler and McDonnell, 2004) was set up in order to understand of the interactions between the riparian forest located at the bottom of the hillslope and the underlying water table. 


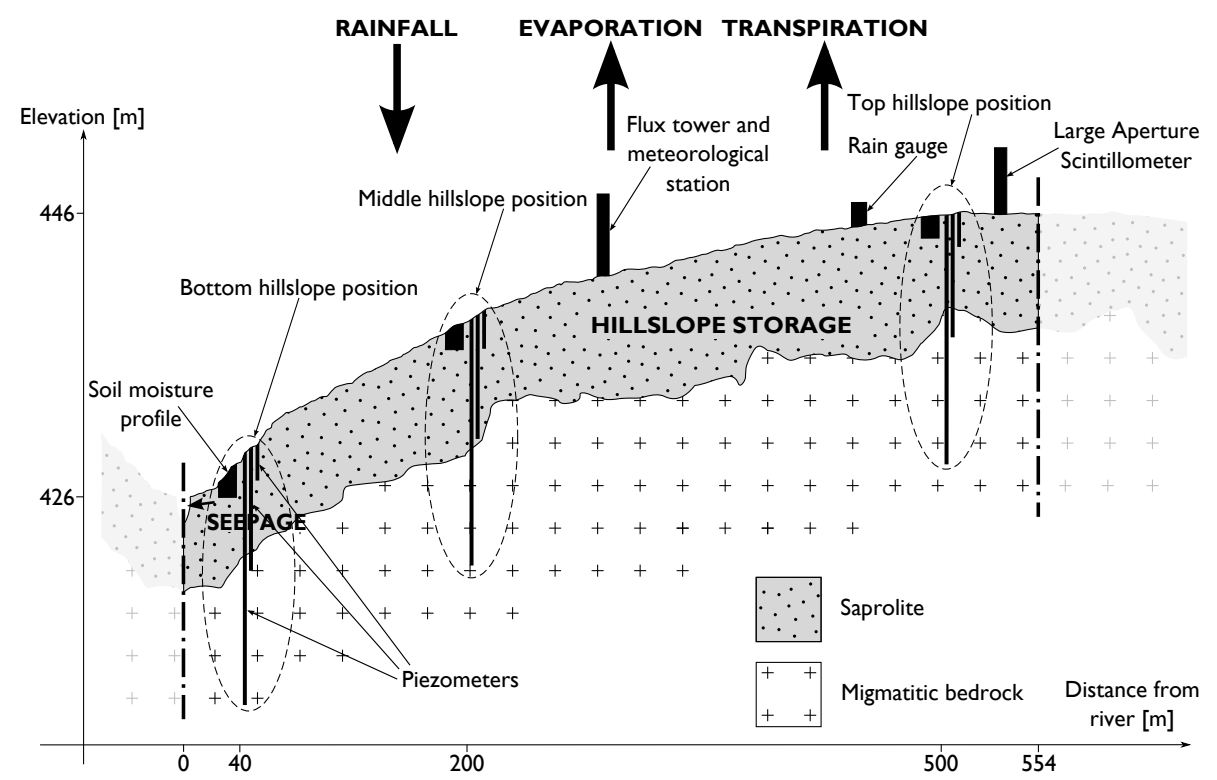

Fig. 2. Schematic hillslope representation (fluxes, water storage, available hydrologic sensors), assuming two axes of symmetry: the river at the bottom of the hillslope and the topographic divide at the top of the hillslope. Only the Large Aperture Scintillometer receiver is illustrated, the transmitter is at the symmetrical position on the opposite hillslope. Vertical stretching: 10 .

\section{Materials}

\subsection{Study site}

The study site is a part of the Sudanian mesoscale site of the AMMA-CATCH observing system (Lebel et al., 2009). It is located in the upper Ouémé catchment in northern Benin, lat $9.74^{\circ} \mathrm{N}$; lon $1.60^{\circ} \mathrm{E}\left(14400 \mathrm{~km}^{2}\right.$, Fig. 1). The upper Ouémé elevation ranges from 230 to $620 \mathrm{~m}$, with a gently inclined slope of about $3 \%$ along the main stream.

The rainfall regime is driven by the InterTropical Convergence Zone (ITCZ) migration, with $65 \%$ of the annual rainfall occurring during three months between July and September (Le Lay and Galle, 2005b) and almost no rainfall from November through March. The mean annual rainfall over the upper Ouémé catchment is $1190 \mathrm{~mm} \mathrm{yr}^{-1}$ for the period 1950-2002 (Le Lay and Galle, 2005b) with a standard deviation of $224 \mathrm{~mm} \mathrm{yr}^{-1}$. The ITCZ migration also determines the wind characteristics: the Harmattan blows dry air from the northeast during the dry season, while the humid wind blowing from the Southern Ocean characterises the wet season. The averaged daily air temperature remains around $26^{\circ} \mathrm{C}$ all year long. At a monthly time step, the reference evapotranspiration $\mathrm{ET}_{0}$ (Allen et al., 1998) shows low seasonal variability, with a maximum of $5-6 \mathrm{~mm} \mathrm{~d}^{-1}$ at the end of the dry season and a minimum of $3-4 \mathrm{~mm} \mathrm{~d}^{-1}$ in the wet season.

Sporadic streamflow lasting a few days may be observed before the monsoon onset depending on the occurrence of isolated rainfalls, especially on small catchments. After the onset (end of June), uninterrupted streamflow is observed un- til the end of the rainy season, and river flow progressively stops in the dry season. Discharge peaks occur from midAugust to the end of September. Total discharge represents about $11 \%$ of the annual rainfall within the upper Ouémé area (Le Lay and Galle, 2005a; Peugeot et al., 2011).

The land use is composed of four main vegetation types over the upper Ouémé: cultivated area with mixed crops and fallows (16\%), shrub savannah (32\%), woody savannah $(42 \%)$, forest $(8 \%)$, leaving about $2 \%$ of urbanised and water body areas (Judex et al., 2009). About $50 \%$ of the surface is or has been cultivated, while $50 \%$ remains practically natural. The riparian forests, even if they cover only a negligible fraction of the landscape $(0.9 \%)$ are commonly found along the stream banks (Séguis et al., 2011b).

The studied hillslope here is entirely cultivated, with alternating crop rotation (yams, maize, cassava, sorghum) and fallows. Its lower part is bordered by a $20 \mathrm{~m}$-wide riparian forest which represents about $5 \%$ of the hillslope length. According to the World Reference Base (IUSS Working Group WRB, 2006), the soils are mainly lixisols on crests and mid-slopes, plinthosols with or without outcrops of hardpan at the slope bottom and thin sandy soils overlying a thick clayey horizon in the bas-fonds (Faure, 1977; Giertz and Diekkrüger, 2003). The French word bas-fonds denotes a tropical, seasonally waterlogged, linear depression in the headwater zones of rivers, frequently without any marked stream channel, and predominantly covered by grass species (Giertz and Diekkrüger, 2003; Séguis et al., 2011b).

The typical soil horizon depths range from 0.15 to $0.4 \mathrm{~m}$ and 0.7 to $1.6 \mathrm{~m}$, for the A and B horizons, respectively; the C horizon lies deeper than $1.6 \mathrm{~m}$ (Faure, 1977). According to 
the USDA soil classification system, the A horizon is loamy sand or sandy loam, the B horizon is sandy clay loam and the $\mathrm{C}$ horizon is sandy clay or sandy clay loam, in line with numerous tropical soils (de Condappa et al., 2008).

The aquifer containing the permanent and unconfined water table is mainly made up of silty and clayey $5-25 \mathrm{~m}$ thick saprolites, overlying the metamorphic (gneiss and micaschist) fractured basement (Affaton, 1987; Descloitres et al., 2011). Hereafter, this permanent and unconfined groundwater is called permanent groundwater. The level of the permanent groundwater table remains approximately parallel to the soil surface all year long and fluctuates between 2 and $5 \mathrm{~m}$ deep (Séguis et al., 2011b).

\subsection{Hydrological data}

The studied hillslope is limited upslope by the topographic divide and downslope by the river. Various sensors were deployed along this hillslope in order to monitor the different hydrological terms (Table 1, Fig. 2): rainfall, evapotranspiration, soil water content, soil water tension and groundwater level. One rain gauge was located on the upper part of the hillslope. Three soil water content and soil water tension measurement profiles were installed at three positions along the hillslope (measurement depths at 0.1, 0.2, 0.4, 0.6 and $1 \mathrm{~m}$ ). These profiles were $40 \mathrm{~m}$ (lower), $198 \mathrm{~m}$ (middle) and $508 \mathrm{~m}$ (upper) from the river: the middle one was located at a slope break on crop and the upper one on vegetation fallow. Three piezometers (2,10 and $20 \mathrm{~m}$ deep) were set up close to each soil profile. One flux tower with eddy covariance (EC) measurements and a meteorological station were installed $100 \mathrm{~m}$ apart from the mid-slope profile (Mamadou et al., 2013). The meteorological station includes measurements of atmospheric pressure, air temperature, relative humidity, wind speed and direction at $2 \mathrm{~m}$ and a complete radiation budget. Additionally, one large aperture scintillometer (LAS) set-up over a $2.4 \mathrm{~km}$ transect complemented the experimental instrumentation. The annual mean distribution of the LAS footprint is composed of $15 \%$ woody savannah (including the riparian forest) and $85 \%$ crops/fallow/bare soil. The actual evapotranspiration was deduced from LAS measurements through the computation of the energy balance at hillslope scale $\left(1 \mathrm{~km}^{2}\right)$ (Guyot et al., 2009) and from EC measurements at local scale (middle slope). Taking into account the numerous measurement gaps, we built a unique time series of actual evapotranspiration, composed of LAS and EC measurements; the LAS values had priority over the EC ones due to their larger and more representative footprint.

The soil physical properties (retention curve and saturated hydraulic conductivity) were derived from field measurements. The collocated soil water content and soil water tension measurements are used to evaluate the retention curve parameters within the first two meters of soil. For deeper layers (from 2 to $7 \mathrm{~m}$ ), soil samples extracted from experimental wells were used to determine the retention curve character-

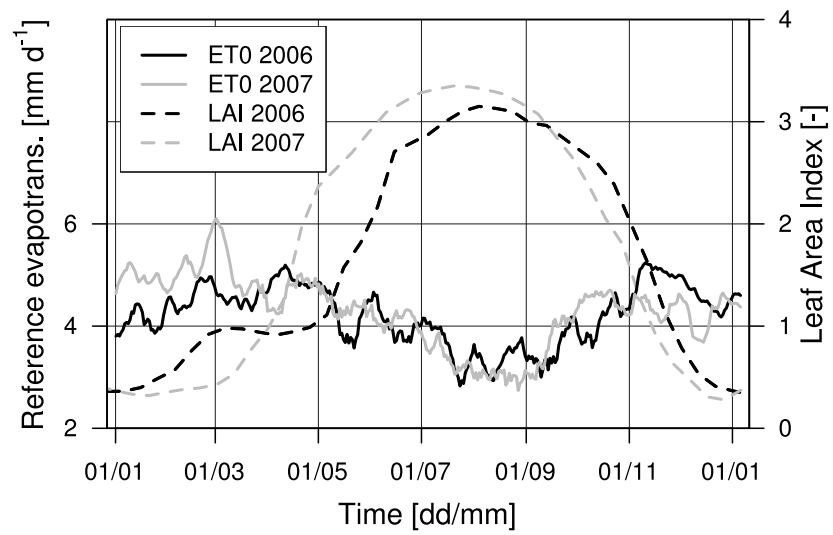

Fig. 3. Annual cycle of the reference evapotranspiration $\mathrm{ET}_{0}(10-$ day moving average filter, solid lines) and of the leaf area index (LAI; averages from a composite of satellite products, dashed lines) for 2006 (black lines) and 2007 (grey lines).

istics, using the mercury intrusion porosimetry method $\mathrm{Xu}$ et al., 1997a, b). Disc infiltrometer measurements (Vandervaere et al., 2000) were used to determine the saturated hydraulic conductivities of the three soil layers (soil 1: $0-0.5 \mathrm{~m}$, soil 2: $0.5-2 \mathrm{~m}$ and soil 3: 2-3 m) down to $3 \mathrm{~m}$ deep (Robert, 2012). The hillslope vegetation dynamics was assessed by a composite leaf area index (LAI) based on a combination of satellite LAI products (CYCLOPE, MODIS, SEVIRI), constrained by in situ measurements derived from hemispherical photographs using the method proposed by Weiss et al. (2004).

\subsection{Studied period}

The study focused on two contrasted years: 2006 (851 mm of rainfall, "dry") and 2007 (1218 mm, "normal”). In 2006, apart from an isolated rainfall $(25 \mathrm{~mm})$ observed midFebruary, the rainy season extended from mid-April to midOctober. In 2007 the rainy season lasted one and a half months longer (April to mid-November). The annual dynamics of the LAI was consequently different between the two years (Fig. 3), particularly during the transition period from the dry to the wet season. The annual dynamics of the reference evapotranspiration was similar for 2006 and 2007 (Fig. 3).

\subsection{Model construction}

Topography and soil conditions along the hillslope are similar, thus the hillslope is studied as a 2-D system, as shown in Fig. 4. To simulate the hydrodynamic functioning of this hillslope, the finite element model Hydrus 2-D (Simunek et al., 2006) was used. This model numerically solves the Richards equation for water flow in variably saturated porous media. The hydraulic soil properties were described with the van Genuchten-Mualem model without considering hysteresis 
Table 1. Characteristics of measurements, instruments, locations sampling intervals and storage intervals.

\begin{tabular}{|c|c|c|c|c|}
\hline Measurement [unit] & Instrument & $\begin{array}{l}\text { Location } \\
\text { depth or } \\
\text { height }[\mathrm{m}]\end{array}$ & $\begin{array}{r}\text { Sampling } \\
\text { interval }\end{array}$ & $\begin{array}{l}\text { Storage } \\
\text { interval }\end{array}$ \\
\hline Air temperature $\left[{ }^{\circ} \mathrm{C}\right]$ & Vaisala WXT510 Capacitive ceramic & 2 & $10 \mathrm{~s}$ & $30 \mathrm{~min}$ \\
\hline Relative humidity [\%] & Vaisala WXT510 Capacitive thin film polymer & 2 & $10 \mathrm{~s}$ & $30 \mathrm{~min}$ \\
\hline Wind speed $\left[\mathrm{m} \mathrm{s}^{-1}\right]$ and direction $\left[{ }^{\circ}\right]$ & Vaisala WXT510 Ultrasonic anemometer & 2 & $10 \mathrm{~s}$ & $30 \mathrm{~min}$ \\
\hline Net radiation $\left[\mathrm{W} \mathrm{m}^{-2}\right]$ & Kipp and Zonen CNR1 & 2 & $10 \mathrm{~s}$ & $30 \mathrm{~min}$ \\
\hline Rainfall [mm] & Précis Mécanique ABS3030 Tipping bucket raingauge & 1 & pulse & $5 \mathrm{~min}$ \\
\hline Volumetric soil water content $\left[\mathrm{m}^{3} \mathrm{~m}^{-3}\right]$ & Campbell Sci. CS616 Water content reflectometer & $\begin{array}{l}-0.1 ;-0.2 \\
-0.4 ;-0.6 \\
-1\end{array}$ & $5 \mathrm{~min}$ & $60 \mathrm{~min}$ \\
\hline Soil water tension $[\mathrm{hPa}]$ & Irrometer Watermark Granular matrix sensor & $\begin{array}{l}-0.1 ;-0.2 \\
-0.4 ;-0.6 \\
-1 ;-2 ;-3\end{array}$ & $5 \mathrm{~min}$ & $60 \mathrm{~min}$ \\
\hline Water table depth $[\mathrm{m}]$ & OTT KL010 Contact gauge piezometer & $\begin{array}{l}-2 ;-10 \\
-20\end{array}$ & $2 \mathrm{~d}$ & $2 \mathrm{~d}$ \\
\hline Sensible heat flux $\left[\mathrm{W} \mathrm{m}^{-2}\right]$ & Campbell Sci. CSAT3 3-D sonic anemometer & 5 & $20 \mathrm{~Hz}$ & $30 \mathrm{~min}$ \\
\hline Latent heat flux [ $\left.\mathrm{W} \mathrm{m}^{-2}\right]$ & Eurosep LI-7500 Open path gas analyser & 5 & $20 \mathrm{~Hz}$ & $30 \mathrm{~min}$ \\
\hline Sensible heat flux $\left[\mathrm{W} \mathrm{m}^{-2}\right]$ & Scintec BLS900 Large aperture scintillometer (LAS) & 5 & $1 \mathrm{~s}$ & $1 \mathrm{~min}$ \\
\hline
\end{tabular}

(van Genuchten, 1980). The values of the 6 parameters used in the van Genuchten-Mualem model are presented in Table 2. The governing flow equation (Richards' equation) includes a sink term $S$ which represents the transpiration term; it is computed using a root water uptake model described by

$S(h)=a(h) S_{t} T_{\mathrm{p}} b(x, z)$,

where $a$ is the water stress response function, depending on the pressure head $h, S_{\mathrm{t}}$ is the soil surface associated with transpiration, $T_{\mathrm{p}}$ is the potential water uptake rate (potential transpiration) and $b(x, z)$ the normalized root water uptake distribution in horizontal $(x)$ and vertical ( $z$ ) dimensions. An S-shaped function (van Genuchten, 1987) was chosen to represent the water stress response function $a$ :

$a(h)=\left\{\begin{array}{l}\frac{1}{1+\left(\frac{h}{h h_{0}}\right)^{p}} \text { for } h>h_{\mathrm{wp}} \\ 0 \text { for } h \leq h_{\mathrm{wp}}\end{array}\right.$.

Classical values (Simunek et al., 2006) were specified for $h_{50}$ (pressure head at which the root water uptake is reduced by $50 \%$ : $-8 \mathrm{~m}$ ), $p$ (exponent parameter of the water stress response function: 3 ) and $h_{\mathrm{wp}}$ (wilting point below which transpiration stops: $-160 \mathrm{~m}$ ). We assumed that $S_{\mathrm{t}}$ (reduced to a length in the 2-D system) corresponded to the whole hillslope, and its value was set to $554 \mathrm{~m}$. According to Ritchie (1972), the reference evapotranspiration $\mathrm{ET}_{0}$ was partitioned into potential evaporation $E_{\mathrm{p}}$ and the poten- tial transpiration $T_{\mathrm{p}}$, depending on the LAI (Eq. 3):

$E_{\mathrm{p}}=\mathrm{ET}_{0} \cdot e^{-K \cdot \mathrm{LAI}}$

$T_{\mathrm{p}}=\mathrm{ET}_{0} \cdot\left(1-e^{-K . \mathrm{LAI}}\right)$,

where $K$ is the extinction coefficient of the canopy for total solar irradiance. Following López-Cedrón et al. (2008), $K$ is prescribed equal to 0.5 . This value was confirmed experimentally on the study site by processing the hemispherical photographs used to estimate the LAI.

Two types of plant root system were defined, crop and tree, characterised by their different rooting depth. The crop root system covers the entire hillslope and, according to observations, most of the roots were located above $0.5 \mathrm{~m}$ deep. We defined $b^{\prime}(x, z)$ as the absolute root water uptake distribution function $b^{\prime}(x, z<0.5)=1$ for any location $x, b^{\prime}(x, z)=0$ otherwise (Fig. 4). The tree root system, corresponding to the riparian forest, was concentrated at the bottom of the slope. The width of the aerial part of the riparian forest was estimated (field surveys) at roughly $20 \mathrm{~m}$, but the corresponding root part may be significantly larger. Moreover, no information on tree roots profiles was available. Consequently, the values of $x_{\text {trees }}$ and $z_{\text {trees }}$ for which $b^{\prime}\left(x<x_{\text {trees }}\right.$, $\left.z<z_{\text {trees }}\right)=1$ were calibrated. The $b(x, z)$ function in Eq. (1) was obtained by normalizing $b^{\prime}(x, z)$ to its integral over the whole domain (such that the integral of $b$ over the domain is equal to unity).

The model geometry was derived from the site topography. The finite element mesh had 6219 nodes with a specified size of $0.5 \mathrm{~m}$ and a stretching factor of 4 . Three soil layer 


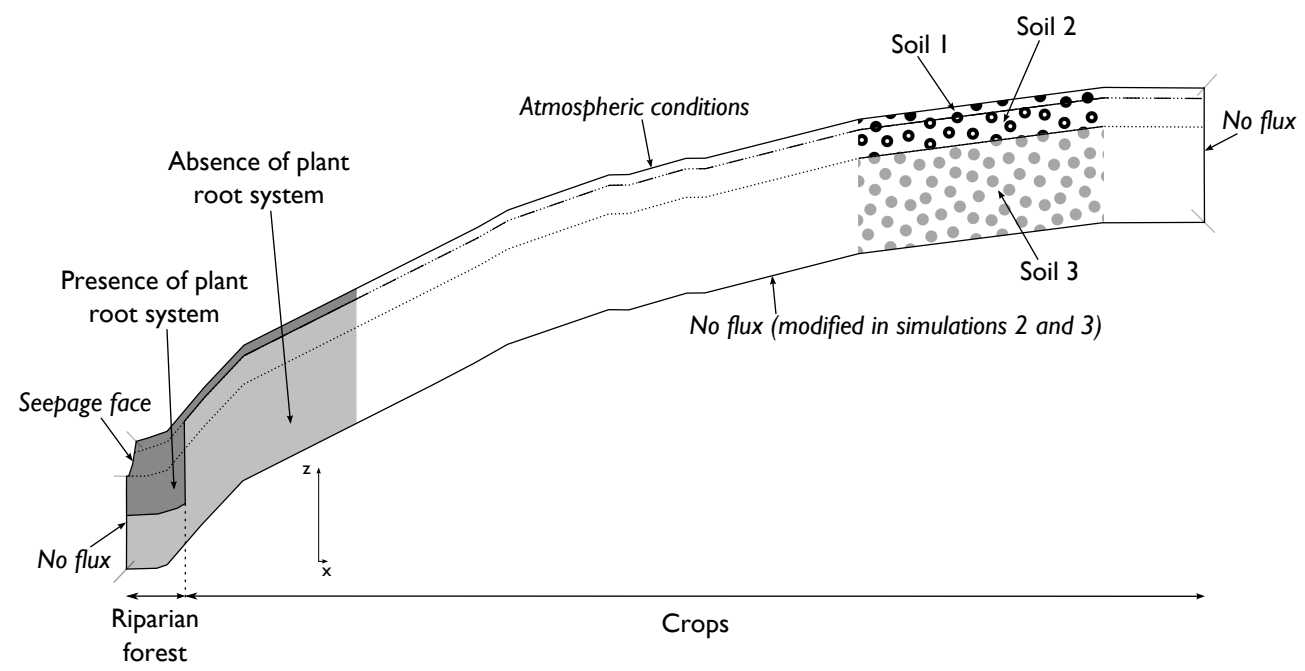

Fig. 4. Schematic of the plant root system distribution and of the soil distribution with indication of the boundary conditions. Left, plant root system distribution. Dark grey corresponds to the region where $b^{\prime}=1$, light grey corresponds to the region where $b^{\prime}=0$. The vertical dashed line shows the lateral extent of the tree root system, fitted to $30 \mathrm{~m}$ ( $5 \%$ of the hillslope length), while the long dashed lines show the continuation of the plant root system distribution upslope. Right, schematic of the 3-layer soil distribution with dotted lines showing its continuation upslope and downslope. Boundary conditions are indicated in italics. Short grey segments separate different boundary conditions. Vertical stretching: 10 .

Table 2. Soil physical parameters used in the van Genuchten-Mualem model for the three soil layers. $\theta_{\mathrm{r}}$ : residual water content; $\theta_{\mathrm{s}}:$ saturated water content; $h_{\mathrm{g}}$ : inflection point pressure; $n$ : pore size distribution parameter; Ks: saturated hydraulic conductivity; $L$ : pore conductivity parameter.

\begin{tabular}{rrrrrrr}
\hline & & & & & \multicolumn{2}{c}{$\begin{array}{c}\text { Hydraulic conductivity } \\
\text { curve parameters }\end{array}$} \\
\hline Variable & $\theta_{\mathrm{r}}\left[\mathrm{m}^{3} \mathrm{~m}^{-3}\right]$ & $\theta_{\mathrm{S}}\left[\mathrm{m}^{3} \mathrm{~m}^{-3}\right]$ & $h_{\mathrm{g}}[\mathrm{m}]$ & $n[-]$ & ${\mathrm{Ks}\left[\mathrm{m} \mathrm{s}^{-1}\right]}$ & $L[-]$ \\
\hline Status & prescribed & prescribed & prescribed & prescribed & calibrated & prescribed \\
\hline Soil 1 & 0.025 & 0.35 & -0.50 & 1.8 & $5.2 \times 10^{-5}$ & 0.5 \\
Soil 2 & 0.090 & 0.35 & -0.28 & 1.6 & $3.5 \times 10^{-5}$ & 0.5 \\
Soil 3 & 0.025 & 0.25 & -1.00 & 1.8 & $1.4 \times 10^{-5}$ & 0.5 \\
\hline
\end{tabular}

bases were identified from field measurements at $0.5 \mathrm{~m}, 2 \mathrm{~m}$ and lower (Robert, 2012). Steady limits are assumed for the three soil layer bases throughout the hillslope (Fig. 4). The third soil layer base is the lower boundary of the domain. It was assumed to be $7 \mathrm{~m}$ deep due to local observation of the bedrock. Knowing that the observed groundwater table fluctuates between 2 and $5 \mathrm{~m}$ deep, the lower boundary is saturated all year long. During the marked dry season, simulated soil water tension at the soil surface is very high due to evaporation. To avoid numerical problems in this configuration, roots are removed for nodes above $0.2 \mathrm{~m}$ depth.

An atmospheric boundary condition is specified at the surface, and a no-flux boundary condition at the lower boundary (Fig. 4). Concerning the upslope (respectively downslope) boundary conditions, a symmetric functioning of divergent fluxes due to the limit of the catchment (convergent fluxes due to river) is assumed, resulting in a no-flux condition. Next to the river, a seepage face boundary condition is prescribed, allowing seepage into the river if the soil is saturated.

The model was initialized during the dry period from 12 October 2005 to 31 December 2005, with a uniform unsaturated water content of $0.23 \mathrm{~m}^{3} \mathrm{~m}^{-3}$ prescribed all over the domain. The model was run with the reference evapotranspiration as unique forcing, and the simulation period began on 1 January 2006. The initial prescribed value had little impact on the water content simulated at the end of the initialization period. The model was run in 2006, and the 2007 simulation was initialized with the model state computed for the last time step of the 2006 simulation. 


\section{Reference simulation and virtual experiment}

\subsection{Model calibration and evaluation}

The aim of the calibration was to obtain a reasonable and plausible model according to the observed internal dynamics. A perfect fit between all data and all model outflows was not targeted. The focus was put on soil water and permanent groundwater to evaluate the internal dynamics and actual evapotranspiration which is the main sink term of the water budget. Retention curve parameters and hydraulic conductivity curve parameters (Table 2) were inferred from measurements for the three soil layers. The saturated hydraulic conductivity was calibrated for each of the three soil layers, but constrained to lie within one order of magnitude of the measured values. The width and depth of the tree root system were calibrated as well by minimizing the differences between observed and predicted values of the water contents at 0.2 and $1 \mathrm{~m}$, and the groundwater level at the top, middle and bottom locations (Fig. 2). Following Keim et al. (2006) the calibration was carried out manually (trial and error process). The quality of the final simulation was visually appraised and was quantified using the KGE performance criterion (Gupta et al., 2009) for each considered variable (Eq. 4).

$\mathrm{KGE}=1-\sqrt{(r-1)^{2}+(\alpha-1)^{2}+(\beta-1)^{2}}$,

$\alpha=\frac{\sigma_{\text {sim }}}{\sigma_{\text {meas }}}$,

$\beta=\frac{\mu_{\text {sim }}}{\mu_{\text {meas }}}$,

with $r$ the Pearson product-moment correlation coefficient, $\alpha$ the ratio between the standard deviation of the simulated values $\left(\sigma_{\text {sim }}\right)$ and the standard deviation of the measured values $\left(\sigma_{\text {meas }}\right), \beta$ the ratio between the mean of the simulated values $\left(\mu_{\text {sim }}\right)$ and the mean of the measured values $\left(\mu_{\text {meas }}\right)$.

The 2006 simulation (calibration) is considered the reference simulation; the model was run on year 2007 with the calibrated values and evaluated.

\subsection{Virtual experiment modelling}

A virtual experiment was performed on the year 2006 in order to understand the interactions of water uptake by the riparian forest, ground transfers, water table level fluctuations and downslope outflows to the river. The virtual experiment was composed of the 2006 reference simulation and three additional simulations summarized in Table 3.

The goal of simulation 1 was to test the impact of the riparian forest on the hillslope water cycle: the tree root system was replaced with the crop root system $(0.2-0.5 \mathrm{~m}$ depth) in the riparian area. However, the LAI time series was not modified, and thus neither was the partitioning of the potential evaporation and the potential transpiration, as defined by
Eq. (3). This issue is discussed in Sect. 5. The potential transpiration was simply reduced proportionally to the change in the root system distribution. In simulation 2, the riparian forest was maintained but a free drainage condition was specified at the bottom of the profile, resulting in the disappearance of the water table. Simulation 3 combined the two others, replacing the riparian forest with crops and setting a free drainage boundary condition.

\section{Results}

\subsection{6 simulation}

The soil physical properties values used in the simulation, either prescribed or calibrated, are summarized in Table 2. It is important to remember that the calibrated saturated hydraulic conductivity was constrained within one order of magnitude of the measured values (Robert, 2012). The calibrated value of the tree roots' depth was $4 \mathrm{~m}$. Tree roots develop in areas where moisture is available (Wan et al., 2002; Peek et al., 2006) but generally not in saturated levels where oxygen lacks. As the observed water table level fluctuates between 2 and $5 \mathrm{~m}$ deep, the calibrated depth value $(4 \mathrm{~m})$ was considered realistic. As expected, the lateral extent of the tree roots $(30 \mathrm{~m})$ is larger than the extent of the riparian forest canopy, as observed on the site $(20 \mathrm{~m})$. In the vicinity of this hillslope, a lateral tree root has been observed $20 \mathrm{~m}$ from a tree. With this calibration the tree and crop root systems respectively represent 17 and $83 \%$ of the total root volume, while the riparian forest covers only $5 \%$ of the surface, against $95 \%$ for the crops.

This simulation is analysed at the daily time step, focusing on its internal hydrodynamics and its water budget. The internal dynamics of the vadose zone and the permanent groundwater table are illustrated in Fig. 5 for the middle and the bottom of the hillslope. The middle hillslope position is representative of the main part of the hillslope (without riparian forest). The bottom position is representative of the hydrodynamics functioning near the riparian forest. Being the lowest instrumented position of the hillslope, the bottom position gathered all the upslope processes. The 2006 calibrated simulation reproduces the main characteristics of the internal dynamics of the vadose zone and that of the permanent groundwater table. Figure 5a and a', which are identical, show the measured rainfall, with an isolated rainfall in February, and the wet season from April to October. The water content dynamics at $0.2 \mathrm{~m}$ depth (Fig. $5 \mathrm{~b}$ and b') are well simulated all year long. These simulated variables are slightly underestimated (about $0.02 \mathrm{~m}^{3} \mathrm{~m}^{-3}$ ) during the dry season. An underestimation also occurs during the heavy rain in September for the bottom profile. During the dry season, the model captures the main characteristics of the water contents at $1 \mathrm{~m}$ depth (Fig. $5 \mathrm{c}$ and c'). For the bottom position at $1 \mathrm{~m}$ depth, the model underestimates the observed water contents in wet 
Table 3. Characteristics of the virtual experiment simulations.

\begin{tabular}{lll}
\hline & Presence of riparian forest & Absence of riparian forest \\
\hline Presence of & 2006 simulation & Simulation 1 \\
deep groundwater & $T_{\mathrm{p}, 2006}(t)$ & $0.83 T_{\mathrm{p}, 2006}(t)$ \\
& PRSD $^{\mathrm{a}}$ : Crop plant, tree & PRSD: Crop plant, no tree \\
& LBC $^{\mathrm{b}}$ : No flux & LBC: No flux \\
\hline Absence of & Simulation 2 & Simulation 3 \\
deep groundwater & $T_{\mathrm{p}, 2006}(t)$ & $0.83 T_{\mathrm{p}, 2006}(t)$ \\
& PRSD: Crop plant, tree & PRSD: Crop plant, no tree \\
& LBC: Free drainage & LBC: Free drainage \\
\hline
\end{tabular}

a Plant root system distribution, ${ }^{\mathrm{b}}$ Lower boundary condition.

season by almost $30 \%$. For the middle position, the baseline of the water content is correctly simulated for the whole year, but three water content peaks occurring during the rainy season are missed. These peak values correspond to the formation of a temporary, shallow water table observed in the field but which is not really simulated as such by the model. The permanent deep groundwater (Fig. 5d and d') displays only a low frequency time variation, as the atmospheric forcing high time frequencies are smoothed out with depth. The simulated and observed groundwater levels are markedly different at the bottom and the middle positions. At the bottom position (Fig. 5d) the simulated amplitude is in good agreement with the measurements but with a 2-month delay. At the middle position a delay, although shorter (1 month), is also observed (Fig. 5d'). In addition, the simulated annual range of the water table depth is lower than the measured one and the water level is about $1 \mathrm{~m}$ deeper than the observed one. In Fig. 6, the simulated evapotranspiration (ET) is compared to the two series of observations (LAS and EC measurements).

ET is well simulated during the wet season, almost reaching the reference evapotranspiration $\mathrm{ET}_{0}$ much in the same way as the observations do. The mean simulated ET is lower than $1 \mathrm{~mm} \mathrm{~d}^{-1}$ during the dry season which is in agreement with the measurements. Moreover, ET is correctly simulated during the transition periods: the beginning of the wet season with an isolated rain event and the decreasing at the end of the wet season. High water velocities are simulated in the permanent groundwater table, increasing downslope (Fig. 7). Velocity vectors are oriented downslope and parallel to the bedrock (not shown in the figure). On the contrary, velocities are small and spatially homogeneous in the vadose zone. The spatial distribution of water velocities keeps this general structure all year long (not shown). Consequently, in terms of mass transfer, the lateral water flux is mainly due to lateral flow in the saturated layer. The synthetic annual hillslope water balance is shown in Fig. 8. Despite a rainy season that does not start until the end of April (black solid line), the cumulative transpiration starts to increase regularly at the end of January; it then increases at a higher and steady rate from the beginning of May (likely as a reaction to the beginning of the rainy season) to the end of November. The annual transpiration represents $73 \%$ of the annual rainfall. The evaporation remains low in dry season and mainly occurs during the wet season, reaching $27 \%$ of the annual rainfall. The seepage term remains negligible all year long, producing no outflow. The change in water storage is calculated by closure of the water balance at the hillslope scale. This term can increase at the daily scale as a response to rainfall events (see for instance the effect induced by the isolated rain event midFebruary, Fig. 8) but globally it decreases until mid-July, because the evapotranspiration rate is significantly greater than the rainfall supply during this period. Then, the water storage increases until the end of the rainy season and finally decreases again to get back to zero; the yearly storage variation for the year 2006 is $0.2 \%$ of the annual rainfall. This means that during this below-normal rainy year, there was neither annual water storage nor seepage. At the annual timescale, evaporation and transpiration compensate rainfall.

\subsection{Model evaluation}

The same variables as those used in Fig. 5 for 2006 are chosen to illustrate the simulation quality for 2007 (Fig. 9). Water contents at $0.2 \mathrm{~m}$ depth at the bottom position (Fig. 9b) and at mid-slope (Fig. 9b') are correctly simulated except for the end of the wet season and the transition period from the wet to the dry season. The simulated water content at the bottom and the middle position was lower and higher than the observed one, respectively. Regarding water contents at $1 \mathrm{~m}$ depth at the bottom position (Fig. 9c) and at mid-slope (Fig. 9c'), the annual dynamics is globally reproduced by the model until a series of large rain events occurs at the beginning of September, the response of the model being much smoother than that of the observations. However, similarly to 2006, the model does not simulate the end of the wet season and the transition period from the wet to the dry season. At mid-slope, the simulated water content reaches the measured maximal water content value at the end of September. This value, close to the saturated water content, is in accordance with measurements but high frequency fluctuations are 

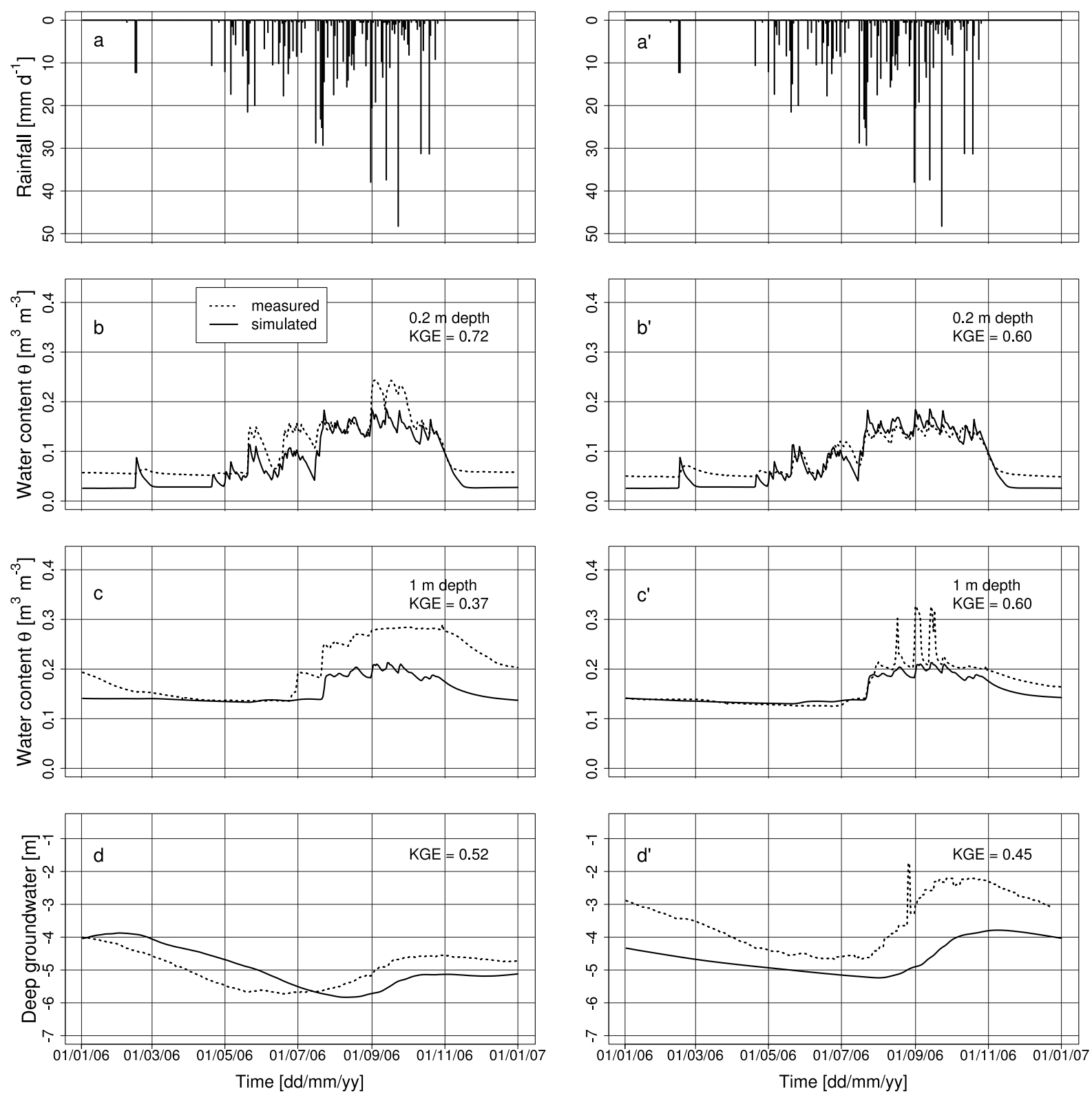

Fig. 5. Forcing variable (rainfall) and state variables of Hydrus 2-D for the 2006 simulation. Graphs on the left are for the bottom of the hillslope; graphs on the right are for the middle of the hillslope. (a, a') measured rainfall; (b, b') measured and simulated water content at $0.2 \mathrm{~m}$ depth; (c, c') measured and simulated water content at $1 \mathrm{~m}$ depth; (d, d') measured and simulated groundwater table level.

missing. Moreover, the simulated maximum value is reached later than the observed one.

The KGE performance criterion is similar in calibration (2006, Fig. 5) and evaluation (2007, Fig. 9) years for water content at 0.2 and $1 \mathrm{~m}$. The level of the permanent groundwater table at mid-slope (Fig. 9d') is well reproduced, the annual fluctuation being correct in both timing and magnitude. For this variable, the evaluation year is better simulated than the calibration one according to the KGE ( 0.58 for year 2007 against 0.45 for year 2006). The simulated values of the permanent groundwater table level at the bottom position are reasonably good during the first part of the year. After rising rapidly in August, the observed permanent water table level at the bottom of the slope reaches a plateau in September and remains stable until December (Fig. 9d); this behaviour is well captured by the model except that the plateau is largely overestimated in the simulation, consequently lowering the KGE criterion in 2007.

Overall, although the Hydrus 2-D simulations did not perfectly reproduce the behaviour of the soil water and water fluxes within the experimental hillslope, the simplified hillslope representation obtained by calibration responds 


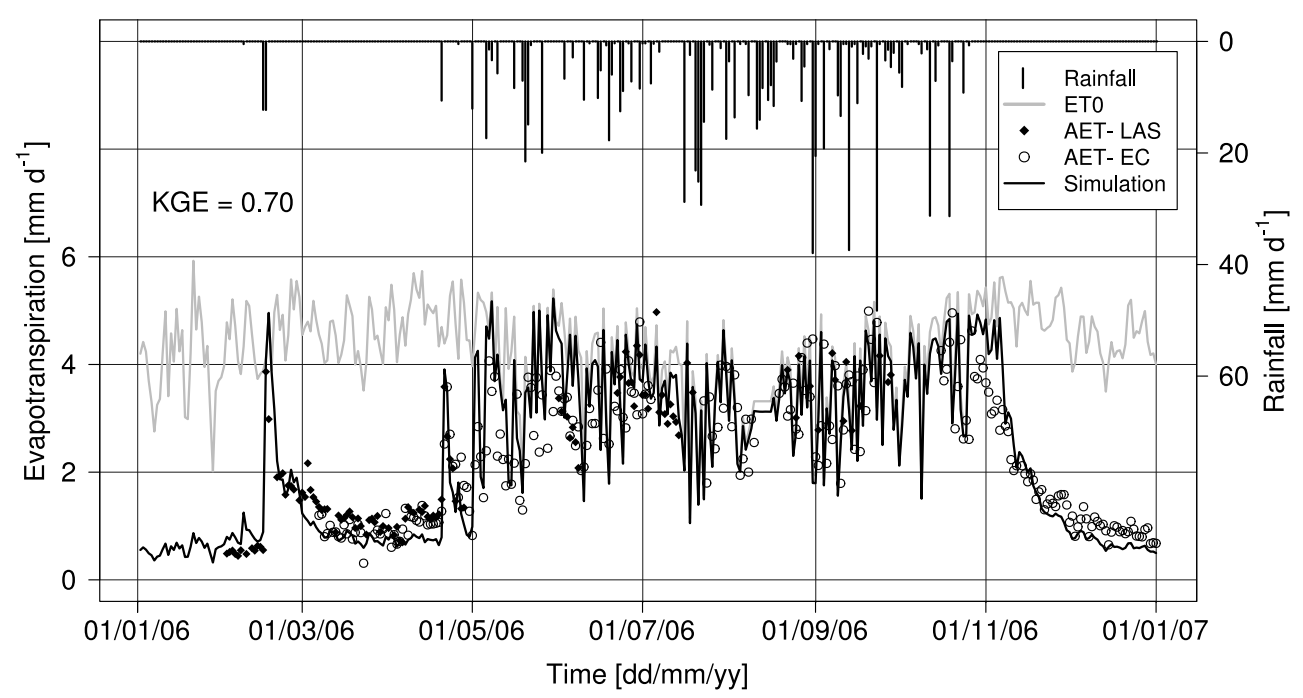

Fig. 6. Simulated and observed evapotranspiration, averaged over the elementary hydrological unit, for year 2006. Actual evapotranspiration is measured by LAS (AET-LAS) or by eddy covariance (AET-EC).

Fig. 7. Simulated water velocity within the hillslope. The black solid line corresponds to the simulated groundwater table. Day of year: 210 (29 July 2006). Vertical stretching: 10.

correctly to the atmospheric forcing for the two different years. Even though some fine tuning of the calibrated parameters could improve the simulation for 2007, our ultimate goal is not to obtain a perfect representation of a single hillslope but rather to obtain an acceptable test bed for setting up a virtual experiment on how the vegetation and the deep groundwater interact and control the hillslope hydrodynamics.

\subsection{Virtual experiment: impacts of riparian forest and permanent groundwater on evapotranspiration}

The virtual experiment is carried out on year 2006. In simulation 1 , the absence of riparian forest results in a reduction of the annual transpiration from 625 to $498 \mathrm{~mm}$ (Table 4). For this simulation, the hillslope generates seepage all year long (not shown) which represents $13 \%$ of the annual rain- fall. The absence of the permanent groundwater (simulation 2) reduces the annual transpiration to $443 \mathrm{~mm}$. For simulation 3 (no riparian forest, no permanent groundwater), seepage is negligible and the annual transpiration decreases to $472 \mathrm{~mm}$, a value close to that of simulation 1 and 2, although there is neither riparian forest nor groundwater.

As explained in Sect. 3.2, the choice was made to keep the potential evaporation time series the same for the four virtual experiment simulations. Consequently, differences between simulations would not result from differences in potential evaporation. The annual evaporation is nearly similar for all the simulations and accounts for 25 to $27 \%$ of the annual rainfall. The negligible variation of the evaporation term between the simulations with and without permanent groundwater suggests a very low impact of the permanent groundwater on the annual evaporation. In the same way, the negligible variation of the evaporation term between the simulations with and without riparian forest shows a very low impact of the tree root system on the annual evaporation. These low differences between simulations are probably due to weak differences in the spatial distribution of water in the hillslope.

\section{Discussion}

\subsection{Riparian forest and permanent groundwater: an interactive transpiration system}

A first important result obtained in this study is the ability of the Hydrus 2-D model to correctly reproduce the annual cycle of the evapotranspiration and its corresponding annual total, using in situ observed properties as much as possible (2006 simulation). The permanent groundwater dynamics is 


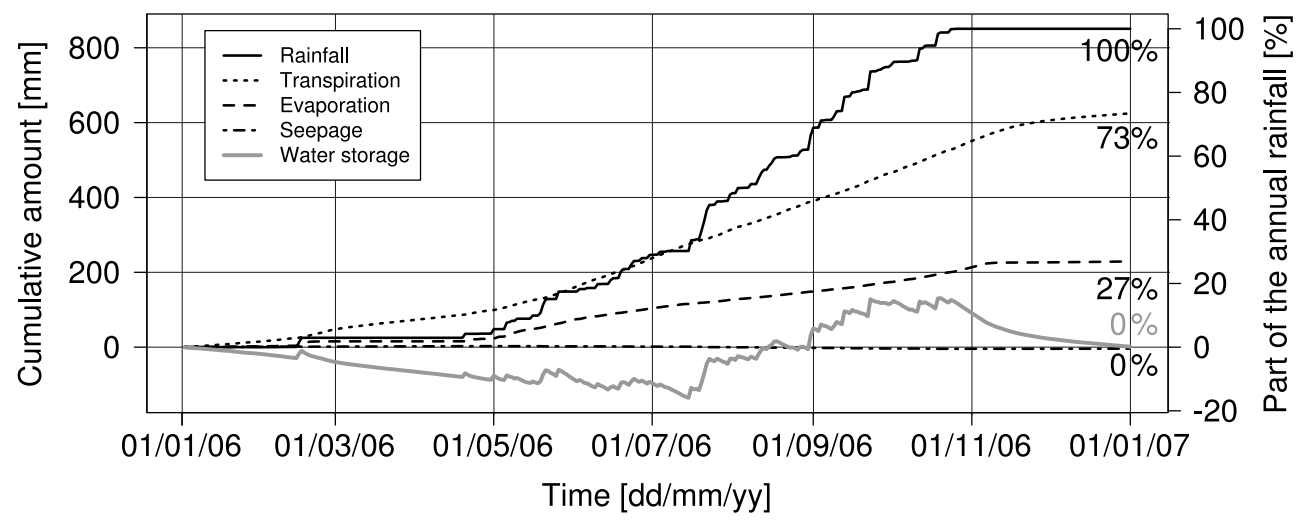

Fig. 8. Synthetic annual water balance of the hillslope: rainfall, transpiration, evaporation, seepage and water storage. All terms are simulated except the rainfall, which is measured. Seepage is close to zero all year long.

Table 4. Summary of the annual output fluxes of the virtual experiment simulations.

\begin{tabular}{|c|c|c|c|c|c|c|}
\hline & \multicolumn{3}{|c|}{ Presence of riparian forest } & \multicolumn{3}{|c|}{ Absence of riparian forest } \\
\hline & & $\begin{array}{r}\text { Annual } \\
\text { value }\end{array}$ & $\begin{array}{r}\% \text { annual } \\
\text { rainfall }\end{array}$ & & $\begin{array}{r}\text { Annual } \\
\text { value }\end{array}$ & $\begin{array}{r}\% \text { annual } \\
\text { rainfall }\end{array}$ \\
\hline \multirow{4}{*}{$\begin{array}{l}\text { Presence of } \\
\text { deep groundwater }\end{array}$} & 2006 simulation & & & Simulation 1 & & \\
\hline & Evaporation & $229 \mathrm{~mm}$ & $27 \%$ & Evaporation & $231 \mathrm{~mm}$ & $27 \%$ \\
\hline & Transpiration & $625 \mathrm{~mm}$ & $73 \%$ & Transpiration & $498 \mathrm{~mm}$ & $59 \%$ \\
\hline & Seepage & $\varepsilon$ & $0 \%$ & Seepage & $114 \mathrm{~mm}$ & $13 \%$ \\
\hline \multirow{4}{*}{$\begin{array}{l}\text { Absence of } \\
\text { deep groundwater }\end{array}$} & Simulation 2 & & & Simulation 3 & & \\
\hline & Evaporation & $226 \mathrm{~mm}$ & $27 \%$ & Evaporation & $215 \mathrm{~mm}$ & $25 \%$ \\
\hline & Transpiration & $443 \mathrm{~mm}$ & $52 \%$ & Transpiration & $472 \mathrm{~mm}$ & $55 \%$ \\
\hline & Seepage & $\varepsilon$ & $0 \%$ & Seepage & $\varepsilon$ & $0 \%$ \\
\hline
\end{tabular}

quite well simulated, implying that the water transfer dynamics between the soil and the atmosphere at the hillslope scale is globally represented by the model.

The virtual experiment (Table 4) allows to further explore the relationships between the riparian forest transpiration and the groundwater. Simulation 3 (no riparian forest, no groundwater) resulted in a $153 \mathrm{~mm}$ reduction of the annual transpiration, as compared to the reference simulation. Simulations 1 and 2 actually represent two possible trajectories to reach the same final state (simulation 3 ). In the first one, the riparian forest was removed first leading to a $127 \mathrm{~mm}$ decrease of the annual transpiration; then, groundwater suppression produced an additional decrease of $26 \mathrm{vmm}$. In the second one the suppression of the groundwater induced loss in transpiration of a $182 \mathrm{~mm}$, and the subsequent conversion of the forest into crops resulted in a slight increase in transpiration (29 mm).

This last result deserves some explanation. Despite a lower potential transpiration (smaller total root volume) in simulation 3, the annual transpiration is higher than in simulation 2 . This can be considered an artefact of the model associated with the formulation of the root distribution function $b(x, z)$
(Eq. 1). The normalisation of the absolute root distribution function $b^{\prime}(x, z)$ by its integral over the whole domain (see Sect. 2.4) actually resulted in a lower value of $b(x, z)$ when the riparian forest was kept, as its integral over the domain was larger (more nodes where $b^{\prime}=1$ ) than that for a crop cover alone. This higher $b^{\prime}$ value over-compensated the reduced potential transpiration.

In short, the first path (suppressing the forest first, then the water table) shows that the transpiration of the riparian forest drives the groundwater depletion, whereas the second path shows that the deep groundwater is necessary to supply the riparian area with water for transpiration. Consequently, riparian forest and deep groundwater constitute an interacting transpiration system.

\subsection{Intra-seasonal variability of the transpiration sources}

In the previous section, the contribution of the riparian forest to the whole transpiration $(153 \mathrm{~mm})$ was estimated by difference between the reference run (2006) and simulation 3, and represents $37 \%$ of the total hillslope transpiration (Fig. 10), 

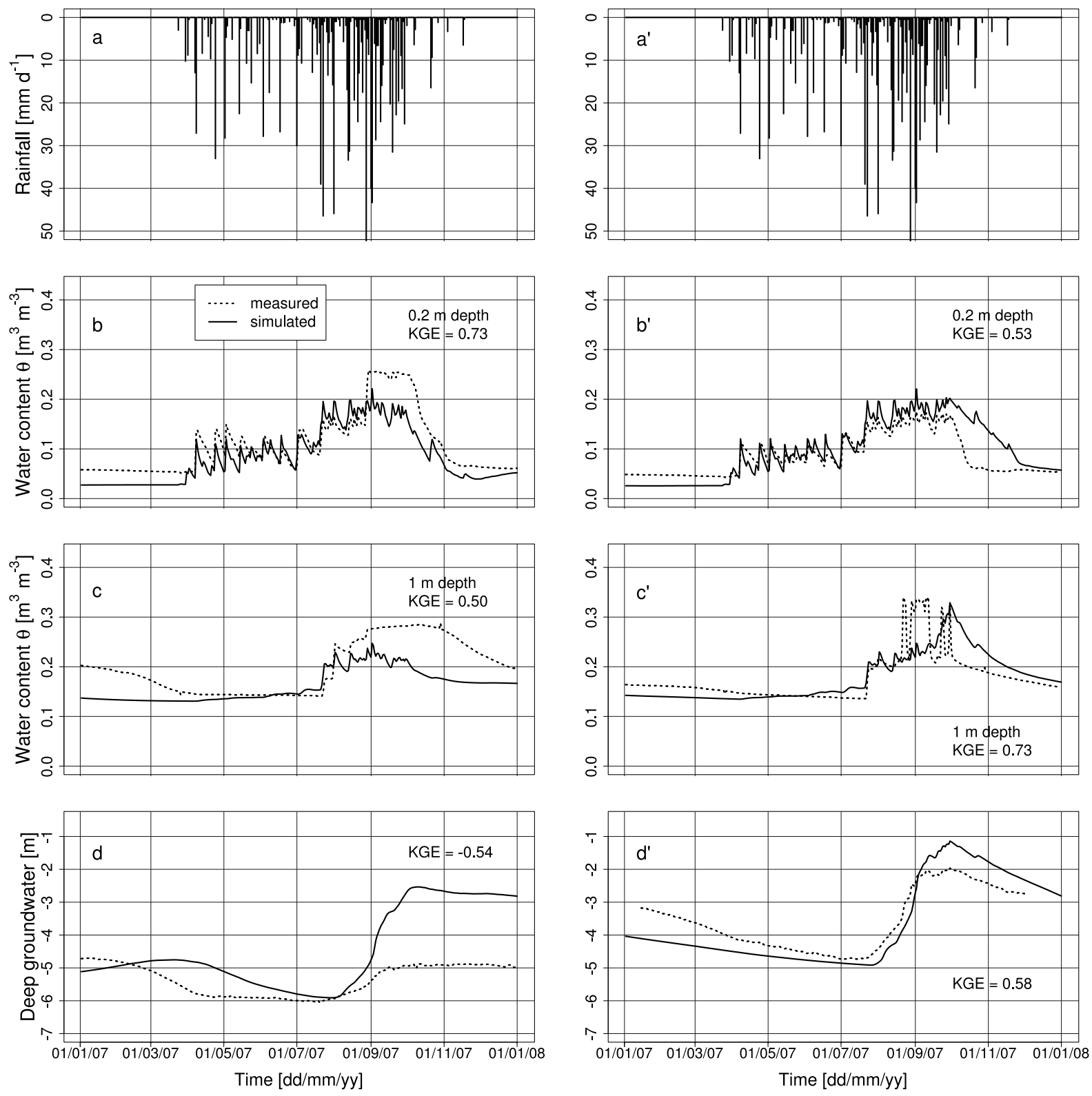

Fig. 9. Forcing variable (rainfall) and state variables of Hydrus 2-D for the 2007 simulation. Graphs on the left are for the bottom of the hillslope; graphs on the right are for the middle of the hillslope. (a, a') measured rainfall; (b, b') measured and simulated water content at $0.2 \mathrm{~m}$ depth; (c, c') measured and simulated water content at $1 \mathrm{~m}$ depth; (d, d') measured and simulated groundwater table level.

even though the riparian forest only amounts to $5 \%$ of the hillslope area and $17 \%$ of the total root volume. Despite a root volume proportionally lower, the contribution of the riparian area to the total transpiration is higher than that of the crop system.

Similar comparison was made for the wet and the dry seasons considered separately. In the wet season, the contribution of the riparian forest to the total transpiration was $19 \%$, close to the proportion of the forest root volume in the whole root system (17\%). Thus, when soil water was not the limiting factor, the extracted water per unit of root volume was roughly equal for crops and riparian forest. By contrast, during the dry season, the upper soil layers were dry and the forest transpiration reached $57 \%$ of the total transpiration, meaning that the riparian forest extracts about six times more water than the other vegetation cover. This result is consistent with former field studies (Dye and Poulter, 1995; Scott, 1999) which showed that the riparian vegetation uses proportionally more water than vegetation further away from the stream. As a result, our study suggests that the total hillslope transpiration is mainly due to the riparian forest in dry season and conversely to the crops during the wet season. 


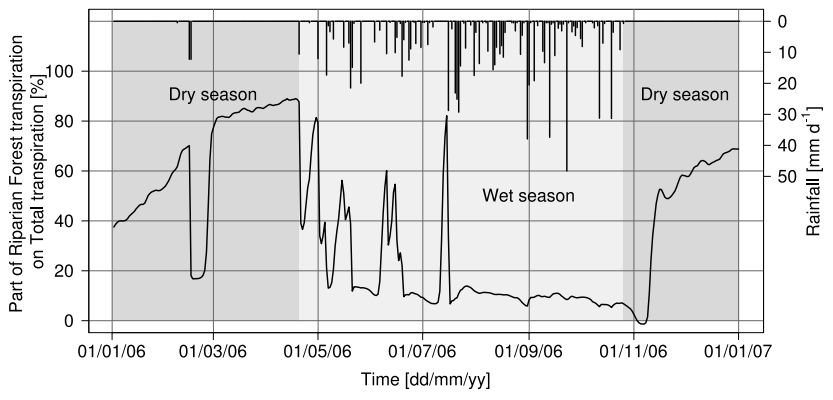

Fig. 10. Part of the riparian forest transpiration on total transpiration (\%) for year 2006. This variable is built by subtracting the transpiration of simulation 3 from the transpiration of the 2006 simulation and then dividing this difference by the transpiration of the 2006 simulation. Rainfall is plotted on the top, scale being on the righthand side. Shaded areas show the dry season (dark grey) and the wet season (light grey).

Hillslope transpiration due to the riparian forest $(153 \mathrm{~mm})$ showed a low daily variability all year long with an average value of $0.41 \mathrm{~mm} \mathrm{~d}^{-1}\left(0.46 \mathrm{~mm} \mathrm{~d}^{-1}\right.$ during the wet season and $0.37 \mathrm{~mm} \mathrm{~d}^{-1}$ during the dry season). Similarly, in the Amazonian context, Markewitz et al. (2010) showed a roughly steady transpiration rate all year long, supplied by deep root uptake. Prorating this deep transpiration to the fraction of riparian forest root width $(30 \mathrm{~m})$ in the hillslope $(554 \mathrm{~m})$, the riparian transpiration reaches $6.9-8.5 \mathrm{~mm} \mathrm{~d}^{-1}$ depending on the season. This result is questionable as these values are 1.9 times higher than the reference evapotranspiration (see Fig. 3). Allen et al. (1998) suggested that for tall vegetation surrounded by shorter cover (so-called clothesline effect) or wet vegetation surrounded by dry land, (so called oasis effect), the reference evapotranspiration must be multiplied by 1.4 to 2.5 to account for the local advection. This range includes our value of 1.9. This ratio depends on the aridity of the surrounding area, the general width of the vegetation stand and the ability of the wind to penetrate into the vegetation cover; 2.5 represents an upper limit linked to the stomatal capacity to supply water vapour to the air stream. In this study, the riparian forest was higher $(8 \mathrm{~m})$ than the crops $(2 \mathrm{~m})$ and the spatial contrast in dry season between the riparian area and the bare soil in the neighbouring fields suggests that the oasis effect can increase advection. As a result, the high transpiration rates obtained in the study were considered realistic. Séguis et al. (2011b) roughly estimated the riparian evapotranspiration rate for the same site between 6 and $34 \mathrm{~mm} \mathrm{~d}^{-1}$. Despite the above-mentioned clothesline effect, the upper value was considered unrealistic by the authors themselves: according to the method they used, this large range of transpiration rates has to be considered a first approximation. Other values can be found in the literature: Lautz (2008) estimated the evapotranspiration rate of a riparian wetland between 0.5 and $3 \mathrm{~mm} \mathrm{~d}^{-1}$ in a semiarid climate; Gazal et al. (2006) obtained $2-7 \mathrm{~mm} \mathrm{~d}^{-1}$ for a semi-arid cottonwood forest; Schilling (2007) calculated a riparian forest evapotranspiration to $5.02-6.32 \mathrm{~mm} \mathrm{~d}^{-1}$ in Iowa and Nachabe et al. (2005) obtained $1.5-6.3 \mathrm{~mm} \mathrm{~d}^{-1}$ for a forest in central Florida. In comparison, the riparian transpiration rates we found here are in the high-end values of these study results.

The surface layer $(0-0.5 \mathrm{~m})$ shows a highly variable transpiration rate, depending on rainfall input, atmosphere demand and soil water availability and is consequently seasondependent. At the annual scale, transpiration can be interpreted as the addition of a practically constant riparian forest transpiration, which is around $0.4 \mathrm{~mm} \mathrm{~d}^{-1}$ at hillslope scale and a time-dependent crop transpiration which is linked to rainfall inputs.

The aim of the virtual experiment was to analyse the impacts of deep groundwater and riparian forest transpiration on the hillslope dynamics. In order to isolate these impacts, we had to maintain other parameters and variables identical as much as possible. It is the case for the potential evaporation and potential transpiration. While the evapotranspiration partition depends on the LAI, we kept the same LAI time series for all the virtual experiment simulations. Actually, replacing the riparian forest by crops should modify the LAI dynamics, as forests and crops do not have the same intra-seasonal variability of LAI. If we assume that vegetation cover without trees has globally lower LAI values, the cover modification we made would have resulted in a decreased potential transpiration and an increased potential evaporation. The related impact on actual evaporation should be low during the dry season because of the dry conditions in the surface layers. In this case, water availability should be the limiting factor of the actual evaporation. During the wet season, the increase in potential evaporation should increase the actual evaporation due to the water availability at the surface. Clearing vegetation also modifies other processes: the decrease of interception losses (Salemi et al., 2012) increases the water availability for evaporation at the soil surface. Vegetation clearing could also stop the hydraulic lift (hydraulic root redistribution in the upward direction) or sap flow downwards (Markewitz et al., 2010). These processes were not accounted in the model and their possible effects on the water distribution, the evaporation and the transpiration fluxes have not been assessed.

\subsection{Year-to-year variability of the simulated functioning}

The model showed overall good performances in calibration (2006, "dry" year) and evaluation (2007, "normal" year), with similar criteria values for both years and for all the diagnosed variables (Figs. 5 and 9), except the water table level at the bottom of the hillslope in 2007 where the lowest KGE was obtained (Fig. 9d). At this particular location, the simulated level was $2 \mathrm{~m}$ higher than observed in 2007 (Fig. 9d), whereas it was close to the observed level at the 
middle location (Fig. 9d'). It means that groundwater inflows at the hillslope bottom were overestimated in the model, or outflows under-estimated, as compared to the actual situation, resulting in a higher water level. Several reasons can be put forward. The hillslope representation used here is simplified: 2-D geometry, uniform physical properties of the soil layers, whereas the actual hillslope, as any other natural system, is much more complex and driven by 3-D rather than 2-D processes. Model calibration allowed "absorbing" most of these discrepancies, leading to a correct overall functioning of the hillslope. With 2007 being much wetter than 2006 $(1218 \mathrm{~mm}$ vs. $851 \mathrm{~mm})$, respectively, non linear processes, such as more active preferential flows, and spatial variability of the soil properties may have lead to inflows at the bottom of the actual hillslope lower than in the model. Perched, seasonal water tables form each year on the basin, with a larger extension in wet years (Kamagaté et al., 2007), and thus reduce the recharge of the permanent water table (and incidentally provide easy-to-use water for transpiration). As these seasonal water tables were not represented in the model, excess water may be supplied to the groundwater, resulting in an overestimated level, especially downslope where lateral flow accumulates (the mid-slope simulated water table level was quite correct).

Conversely, insufficient water outflow in the model can result from too low riparian uptake or seepage into the river. Dunford and Fletcher (1947) on the Coweeta Experimental Forest, showed that a riparian forest could actually extract more water than expected. Following Jarvis (1989), another possible cause of insufficient water outflow is a compensation effect where reduced transpiration in the water-stressed parts of the root zone is balanced by increased transpiration in other parts. In other words, vegetation could extract more water than expected in deep and wet layers because of dry conditions in shallow layers. This process was not accounted in this study.

The bias in the water table level downslope in 2007 is potentially due to a combination of all these factors, but it was not possible to further discriminate between them.

\subsection{Disconnection between the deep groundwater table and the river}

There is another important consequence of the riparian forest and of permanent water table joint functioning: in the model the forest transpiration depletes the groundwater table at such a level that it cannot contribute to the river flow. This is evidenced by comparing the significant seepage $(13 \%$ of the annual rainfall) produced by simulation 1 (absence of riparian forest) to the absence of seepage produced in the 2006 simulation. Since these two simulations differ only by the absence/presence of the riparian forest, this suggests that when the riparian forest is removed, the groundwater table rises to a level allowing it to feed the flow in the river bed. The same conclusion stems from the comparison of simulation 1

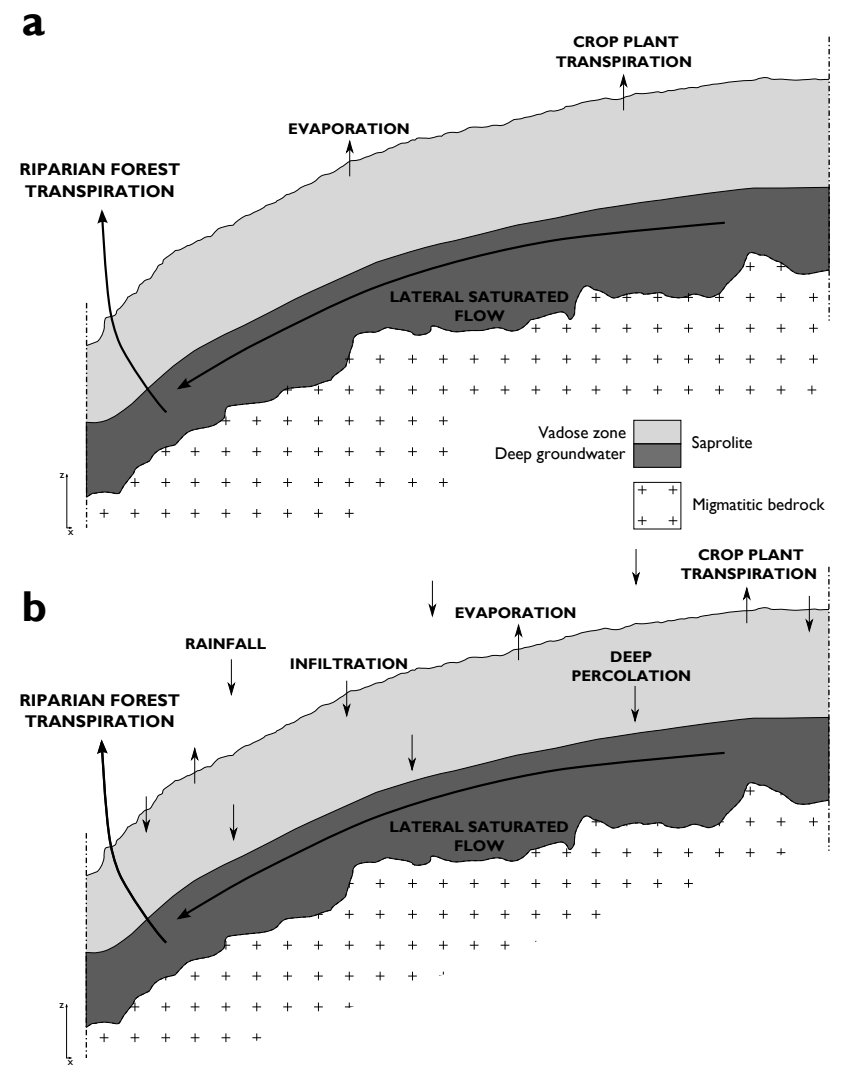

Fig. 11. Schematic hillslope hydrodynamics during the two contrasted seasons: dry season (a), wet season (b). Vertical stretching.

to simulation 3 (differing only by the presence/absence of the groundwater level); the riparian forest being absent in both cases, the absence of seepage in simulation 3 means that the seepage obtained in simulation 1 is produced by the permanent groundwater. This significant seepage is really produced by the rise of the simulated permanent groundwater table above the river bed (not shown). These results suggest that the transpiration of the riparian forest leads to the hydraulic disconnection of the permanent water table and the river. This situation was already put forward by Séguis et al. (2011b) on the Donga catchment (Benin), in which our study site is included. Dye and Poulter (1995) noted that streamflow can also supply the riparian transpiration. In our study, this possibility has not been considered, as the numerical condition at the streambank boundary (seepage) did not allow incoming water flow. Addressing this issue could be done in a further study.

\subsection{Synthesis: overall schematic of the hillslope hydrodynamic functioning}

The schematic of the hillslope hydrodynamics can be summarised as follows. During the dry season (Fig. 11a), only low evaporation and crop plant transpiration take place along the hillslope due to the absence of rainfall events. During 
the wet season (Fig. 11b), rainfall infiltration makes water available for evaporation, crop transpiration, water distribution along the hillslope and percolation that supplies the permanent groundwater. In both seasons, the permanent groundwater flows laterally downslope. Lateral flow from areas far away from the stream provides water to the riparian forest transpiration, as also identified for example by Gribovszki et al. (2008); in turn, the riparian transpiration significantly depletes the water table and causes its hydraulic disconnection from the river, as observed in the field.

On the study site, the streamflow is not supplied by the groundwater discharge, which is hydraulically disconnected from the river, but mainly by subsurface flows (Kamagaté et al., 2007). However field inspections in 2006 revealed no exfiltration ever visually observed at the bottom of this particular hillslope (but it could have happened between two visits), even though temporary saturated levels have occurred within the hillslope (Séguis et al., 2011b). Our modelling results are consistent with these observations as we found that water extraction by the riparian transpiration can explain the absence of drainage to the river. However, it cannot be concluded whether the representation of subsurface flow and perched water tables would change this statement.

Conversely, exfiltration of subsurface flow has been observed in a neighbouring bas-fond. These waterlogged headwater zones are very common in the region and are considered to play a major role in the hydrological regimes in Africa (Balek and Perry, 1973; Bullock, 1992; Giertz and Diekkrüger, 2003; Séguis et al., 2011a) but this assumption remains disputed (for a review, see von der Heyden, 2004). In our area, these bas-fonds, mainly covered with grass, have no riparian vegetation (for reasons unknown to the authors) which, according to our study, can explain the occurrence of exfiltration downslope and consequently generate streamflow.

Supposing that riparian forest was cut (simulation 1), we can suggest that the river flow would have increased because the water table at the bottom of the hillslope would have risen in such a way that it would have discharged into the river. This possible modification of the streamflow generation, derived from the virtual experiment is in agreement with the numerous field studies which demonstrated the increase of the water yield after clear cutting of riparian vegetation (Dunford and Fletcher, 1947; Ingebo, 1971; Dye and Poulter, 1995; Scott, 1999). However, such an extrapolation has to be done carefully because of the complex adaptation of riparian vegetation to new conditions. In a review paper, Brown et al. (2005) showed that the impacts of regrowth experiments on the water yield and the time needed to reach a new equilibrium under permanent land use were driven by complex, not-intuitive interactions.

\section{Summary, conclusion and perspectives}

The water cycle in West Africa plays a key role in the monsoon dynamics, and thus its representation in numerical models has to be integrated across disciplines and scales. In Sudanian West Africa, the mesoscale water budget closure is still different from one model to another (Peugeot et al., 2011). It is especially true for evapotranspiration, which is the main sink term of the water budget. Knowing that riparian forests are a key landscape feature in this region, this study focused on the interplay of riparian forests and groundwater of a wellinstrumented, $550 \mathrm{~m}$-long hillslope in Benin. Previous studies based on field observations showed that the annual water table level fluctuations are driven by the combined effects of infiltration, transpiration, evaporation, and lateral flows which redistribute water at the hillslope scale. However, as frequently observed in the region, the water table is disconnected from the river stream lying at the bottom of the hillslope, and previous studies have assumed that this was mainly caused by water uptake by riparian vegetation.

The hillslope as well as the downslope riparian zone were represented by a 2-D vertical system with the Hydrus model (Simunek et al., 2006). A virtual experiment, based on a reference simulation, was designed. The three other simulations of the virtual experiment explored the following configurations: (i) suppression of the riparian forest, (ii) free drainage at the base of the system to prevent the formation of a water table, and (iii) the combination of both. The model satisfactorily simulated water transfers between the soil and the atmosphere at the hillslope scale: the observed dynamics of soil water, water table levels and evapotranspiration were globally well reproduced. The simulated water table was deeper than the river bed, as observed, due to groundwater depletion by the riparian forest transpiration. The virtual experiment showed that the riparian vegetation and the water table were an interacting system, and we estimated that the riparian forest provided the main part (57\%) of the dry season hillslope transpiration.

Further investigations should continue along three main lines, spanning a hierarchy of scales. First, the ability of a 2-D physical model to account for the main coupling processes between soil water and evapotranspiration at the hillslope scale makes it an important tool for testing and improving our understanding of hydrological processes over a broad range of scales. However, a better identification of subsurface processes producing seepage remains needed for finely representing the intra-seasonal fluctuations of the river flow at the outlet of small catchments. This production is likely limited to particular places of the basin like bas-fonds. Finding a way to introduce this process simultaneously to currently known processes in a Hydrus-like model remains an interesting challenge. Then, riparian areas are not the only zones where deep-rooted vegetation could interact with groundwater, as isolated trees or clump of trees are frequently encountered everywhere in the landscape. The same kind of 
analysis should be addressed by appropriate complementary field campaigns and numerical studies in order to have a more comprehensive knowledge of the hydrological functioning at larger scale, specially concerning dry season transpiration. The last important issue is to improve the representation of the interactions between saturated and unsaturated soil water and deep-rooted trees (either located in riparian areas or apart from them) in hydrological and, more generally, land surface models. It would result in a better simulation of the meso-scale water budgets, and more sound evaluations of the water resources and their renewal dynamics in the region.

Acknowledgements. This research was funded by IRD and INSU in the framework of the AMMA program. Based on a French initiative, AMMA was developed by an international scientific group and funded by a large number of agencies, especially from Africa, European Community, France, UK and USA. More information on the scientific coordination and funding is available on the AMMA International web-site: http://www.amma-international.org. The AMMA-CATCH observing system has been funded since 2001 by IRD, INSU and the French Ministry of Research: http://www.amma-catch.org/ in cooperation with Direction Générale de l'Eau (DG-Eau) of Benin. The article processing charges have been funded by INSU-CNRS. The authors wish to particularly thank the researchers and students who helped them throughout the different steps of this work: T. Lebel, C. Legout, I. Zin, D. Robert, S. Soubeyran, B. Hector, M. Wubda, the Beninese technicians T. Ouani S. Afouda for their permanent support in the field and finally the two anonymous reviewers for their kind and enriching comments.

\section{Edited by: G. Jewitt}

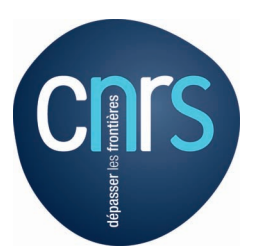

The publication of this article is financed by CNRS-INSU.

\section{References}

Affaton, P.: Le bassin des Volta (Afrique de l'Ouest): une marge passive, d'age proterozoique superieur, tectonisee au panafrican $(600+-50 \mathrm{ma})$, Ph.D. Thesis, University of Aix-Marseille 3, France, 1987.

Allen, R. G., Pereira, L. S., Raes, D., and Smith, M.: Crop evapotranspiration?: guidelines for computing crop water requirements, Irrig. and Drain. Paper no. 56, Food and Agriculture Organization of the United Nations, Rome, Italy, 300 pp., 1998.

Balek, J. and Perry, J. E.: Hydrology of seasonally inundated African headwater swamps, J. Hydrol., 19, 227-249, 1973.

Beven, K. J. and Kirby, M. J.: A physically based, variable contributing area model of basin hydrology, Hydrolog. Sci. J., 24, 43-69, 1979.

Brown, A. E., Zhang, L., McMahon, T. A., Western, A. W., and Vertessy, R. A.: A review of paired catchment studies for deter- mining changes in water yield resulting from alterations in vegetation, J. Hydrol., 310, 28-61, 2005.

Bullock, A: The role of dambos in determining river flow regimes in Zimbabwe, J. Hydrol., 134, 349-372, 1992.

Butler, J. J., Kluitenberg, G. J., Whittemore, D. O., Loheide II, S. P., Jin, W. Billinger, M. A., and Zhan, X.: A field investigation of phreatophyte-induced fluctuations in the water table, Water Resour. Res., 43, W02404, doi:10.1029/2005WR004627, 2007.

Chevallier, P. and Planchon, O.: Hydrological processes in a small humid savanna basin (Ivory Coast), J. Hydrol., 151, 173-191, 1993.

de Condappa, D., Galle, S., Dewandel, B., and Haverkamp, R.: Bimodal zone of the soil textural triangle: common in tropical and subtropical regions, Soil Sci. Soc. Am. J., 72, 33-40, 2008.

Descloitres, M., Séguis, L., Legchenko, A., Wubda, M., Guyot, A., and Cohard, J.-M.: The contribution of MRS and resistivity methods to the interpretation of actual evapo-transpiration measurements: a case study in metamorphic context in north Bénin, Near Surf. Geophys., 9, 187-200, 2011.

Dunford, E. G. and Fletcher, P., W.: Effect of removal of streambank vegetation upon water yield, EOS T. Am. Geophys. Un., 28, 105-110, 1947.

Dye, P. J. and Poulter, A. G.: A Field Demonstration of the Effect on Streamflow of Clearing Invasive Pine and Wattle Trees from a Riparian Zone, South. Forests, 173, 27-30, 1995.

Faure, P.: Carte Pedologique de Reconnaissance au 1/200000e, Feuille de Djougou, Orstom editions, Paris, France, 1977.

Fontaine, B., Philippon, N., and Camberlin, P.: An improvement of June-September rainfall forecasting in the Sahel based upon region April-May moist static energy content (1968-1997), Geophys. Res. Lett., 26, 2041-2044, 1999.

Gazal, R. M., Scott, R. L., Goodrich, D. C., and Williams, D. G.: Controls on transpiration in a semiarid riparian cottonwood forest, Agr. Forest Meteorol., 137, 56-67, 2006.

Giertz, S. and Diekkrüger, B.: Analysis of the hydrological processes in a small headwater catchment in Benin (West Africa), Phys. Chem. Earth, 28, 1333-1341, 2003.

Giertz, S., Diekkrüger, B., and Steup, G.: Physically-based modelling of hydrological processes in a tropical headwater catchment (West Africa) - process representation and multicriteria validation, Hydrol. Earth Syst. Sci., 10, 829-847, doi:10.5194/hess-10-829-2006, 2006.

Gribovszki, Z., Kalicz, P., Szilágyi, J., and Kucsara, M.: Riparian zone evapotranspiration estimation from diurnal groundwater level fluctuations, J. Hydrol., 349, 6-17, 2008.

Gupta, H. V., Kling, H., Yilmaz, K. K., and Martinez, G. F.: Decomposition of the mean squared error and NSE performance criteria: implications for improving hydrological modelling, J. Hydrol., 377, 80-91, 2009.

Guyot, A., Cohard, J.-M., Anquetin, S., Galle, S., and Lloyd, C. R.: Combined analysis of energy and water balances to estimate latent heat flux of a sudanian small catchment, J. Hydrol., 375, 227-240, 2009.

Guyot, A., Cohard, J.-M., Anquetin, S., and Galle, S.: Long-term observations of turbulent fluxes over heterogeneous vegetation using scintillometry and additional observations: a contribution to AMMA under Sudano-Sahelian climate, Agr. Forest Meteorol., 154-155, 84-98, 2012. 
Ingebo, P. A.: Suppression of Channel-Side Chaparral Cover Increases Streamflow, J. Soil Water Conserv., 26, 79-81, 1971.

IUSS Working Group WRB: World reference base for soil resources 2006, World Soil Resources no. 103, Food and Agriculture Organization of the United Nations, Rome, Italy, 122 pp., 2006.

Jarvis, N. J.: A Simple Empirical Model of Root Water Uptake, J. Hydrol., 107, 57-72, 1989.

Judex, M., Thamm, H.-P., and Menz, G.: Utilisation des Terres et Occupation du Sol Dans le Centre du Bénin, in: IMPETUS Atlas du Benin. Résultats de Recherche 2000-2007, edited by: Judex, M., Thamm, H.-P., Rohrig, J., and Schulz, O., Département de Géographie, Université de Bonn, Allemagne, 85-86, 2009.

Kamagaté, B., Séguis, L., Favreau, G., Seidel, J.-L., Descloitres, M., and Affaton, P.: Hydrological processes and water balance of a tropical crystalline bedrock catchment in Benin (Donga, upper Ouémé River), C. R. Geosci., 339, 418-429, 2007.

Keim, R. F., Tromp-van Meerveld, H. J., and McDonnell, J. J.: A virtual experiment on the effects of evaporation and intensity smoothing by canopy interception on subsurface stormflow generation, J. Hydrol., 327, 352-364, 2006.

Koster, R. D., Dirmeyer, P. A., Guo, Z., Bonan, G., Chan, E., Cox, P., Gordon, C. T., Kanae, S., Kowalczyk, E., Lawrence, D., Liu, P., Lu, C.-H., Malyshev, S., McAvaney, B., Mitchell, K., Mocko, D., Oki, T., Oleson, K., Pitman, A., Sud, Y. C., Taylor, C. M., Verseghy, D., Vasic, R., Xue, Y., and Yamada, T.: Regions of Strong Coupling Between Soil Moisture and Precipitation, Science, 305, 1138-1140, 2004.

Lafforgue, A.: Etude Hydrologique des Bassins Versants de Sakassou: Cote d'Ivoire, 1972-1977, Orstom editions, Paris, 1982.

Lautz, L. K.: Estimating groundwater evapotranspiration rates using diurnal water-table fluctuations in a semi-arid riparian zone, Hydrogeol. J., 16, 483-497, 2008.

Le Lay, M. and Galle, S.: How changing rainfall regimes may affect the water balance: a modelling approach in West Africa, in: Regional hydrological impacts of climatic change: hydroclimatic variability: proceedings, IAHS Publication, 296, edited by: Franks, S., Wagener, T., Bogh, E., Gupta, H. V., Bastidas, L., Nobre, C., and De Oliveira Galvao, C., Wallingford, UK, 203-210, 2005a.

Le Lay, M. and Galle, S.: Seasonal cycle and interannual variability of rainfall at hydrological scales. The West African monsoon in a Sudanese climate, Hydrolog. Sci. J., 50, 509-524, 2005b.

Le Lay, M., Saulnier, G.-M., Galle, S., Séguis, L., Métadier, M., and Peugeot, C.: Model representation of the Sudanian hydrological processes: Application on the Donga catchment (Benin), J. Hydrol., 363, 32-41, 2008.

Lebel, T. and Ali, A.: Recent trends in the Central and Western Sahel rainfall regime (1990-2007), J. Hydrol., 375, 52-64, 2009.

Lebel, T., Cappelaere, B., Galle, S., Hanan, N., Kergoat, L., Levis, S., Vieux, B., Descroix, L., Gosset, M., Mougin, E., Peugeot, C., and Séguis, L.: AMMA-CATCH studies in the Sahelian region of West-Africa: an overview, J. Hydrol., 375, 3-13, 2009.

Loheide II, S. P., Butler, J. J., and Gorelick, S. M.: Estimation of groundwater consumption by phreatophytes using diurnal water table fluctuations: A saturated-unsaturated flow assessment, Water Resour. Res., 41, W07030, doi:10.1029/2005WR003942, 2005.

López-Cedrón, F. X., Boote, K. J., Piñeiro, J., and Sau, F.: Improving the CERES-Maize model ability to simulate water deficit im- pact on maize production and yield components, Agron. J., 100, 296-307, 2008.

Mamadou, O., Cohard, J. M., Galle, S., Awanou, C. N., Diedhiou, A., Kounouhewa, B., and Peugeot, C.: Energy fluxes and surface characteristics over a cultivated area in Benin: daily and seasonal dynamics, Hydrol. Earth Syst. Sci. Discuss., 10, 10605-10657, doi:10.5194/hessd-10-10605-2013, 2013.

Markewitz, D., Devine, S., Davidson, E. A., Brando, P., and Nepstad, D. C.: Soil moisture depletion under simulated drought in the Amazon: impacts on deep root uptake, New Phytol., 187, 592-607, 2010.

Masiyandima, M. C., van De Giesen, N., Diatta, S., Windmeijer, P. N., and Steenhuis, T. S.: The hydrology of inland valleys in the sub-humid zone of West Africa: rainfall-runoff processes in the M'be experimental watershed, Hydrol. Process., 17, 1213-1225, 2003.

Nachabe, M., Shah, N., Ross, M., and Vomacka, J.: Evapotranspiration of two vegetation covers in a shallow water table environment, Soil Sci. Soc. Am. J., 69, 492-499, 2005.

Natta, A. K., Sinsin, B., and van der Maesen, L. J. G.: Riparian forests, a unique but endangered ecosystem in Benin, Bot. Jahrb. Syst., 124, 55-69, 2002.

Nepstad, D. C., de Carvalho, C. R., Davidson, E. A., Jipp, P. H., Lefebvre, P. A., Negreiros, G. H., da Silva, E. D., Stone, T. A., Trumbore, S. E., and Vieira, S.: The role of deep roots in the hydrological and carbon cycles of Amazonian forests and pastures, Nature, 372, 666-669, 1994.

Peek, M. S., Leffler, A. J., Hipps, L., Ivans, S., Ryel, R. J., and Caldwell, M. M.: Root turnover and relocation in the soil profile in response to seasonal soil water variation in a natural stand of Utah juniper (Juniperus osteosperma), Tree Physiol., 26, 14691476, 2006.

Peugeot, C., Guichard, F., Bock, O., Bouniol, D., Chong, M., Boone, A., Cappelaere, B., Gosset, M., Besson, L., Lemaître, Y., Séguis, L., Zannou, A., Galle, S., and Redelsperger, J.-L.: Mesoscale water cycle within the West African Monsoon, Atmos. Sci. Lett., 12, 45-50, 2011.

Philippon, N. and Fontaine, B.: The relationship between the Sahelian and previous 2 nd Guinean rainy seasons: a monsoon regulation by soil wetness?, Ann. Geophys., 20, 575-582, 2002, http://www.ann-geophys.net/20/575/2002/.

Ritchie, J. T.: Model for predicting evaporation from a row crop with incomplete cover, Water Resour. Res., 8, 1204-1213, 1972.

Robert, D.: Caractérisation et modélisation de la dynamique de l'évapotranspiration en Afrique soudanienne en zone de socle, Ph.D. Thesis, Université de Grenoble, France, 2012.

Salemi, L. F., Groppo, J. D., Trevisan, R., Marcos de Moraes, J., de Paula Lima, W., and Martinelli, L. A.: Riparian vegetation and water yield: A synthesis, J. Hydrol., 454-455, 195-202, 2012.

Schilling, K. E.: Water table fluctuations under three riparian land covers, Iowa (USA), Hydrol. Process., 21, 2415-2424, 2007.

Scott, D. F.: Managing riparian zone vegetation to sustain streamflow: results of paired catchment experiments in South Africa, Can. J. Forest Res., 29, 1149-1157, 1999.

Séguis, L., Boulain, N., Cappelaere, B., Cohard, J. M., Favreau, G., Galle, S., Guyot, A., Hiernaux, P., Mougin, E., Peugeot, C., Ramier, D., Seghieri, J., Timouk, F., Demarez, V., Demarty, J., Descroix, L., Descloitres, M., Grippa, M., Guichard, F., Kamagaté, B., Kergoat, L., Lebel, T., Le Dantec, V., Le Lay, M., 
Massuel, S., and Trichon, V.: Contrasted land-surface processes along the West African rainfall gradient, Atmos. Sci. Lett., 12, 31-37, 2011a.

Séguis, L., Kamagaté, B., Favreau, G., Descloitres, M., Seidel, J.-L., Galle, S., Peugeot, C., Gosset, M., Le Barbé, L., Malinur, F., Van Exter, S., Arjounin, M., Boubkraoui, S., and Wubda, M.: Origins of streamflow in a crystalline basement catchment in a sub-humid Sudanian zone: the Donga basin (Benin, West Africa), J. Hydrol., 402, 1-13, 2011b.

Simunek, J., van Genuchten, M. T., and Sejna, M.: The HYDRUS software package for simulating the two- and three-dimensional movement of water, heat, and multiple solutes in variablysaturated media, Technical Manual, PC-Progress, Prague, Czech Republic, 2006.

van Genuchten, M. T.: A closed-form equation for predicting the hydraulic conductivity of unsaturated soils, Soil Sci. Soc. Am. J., 44, 892-898, 1980.

van Genuchten, M. T.: A numerical model for water and solute movement in and below the root zone, Research Report, US Salinity laboratory, USDA, Riverside, California, 1987.

Vandervaere, J.-P., Vauclin, M., and Elrick, D. E.: Transient flow from tension infiltrometers: II. Four methods to determine sorptivity and conductivity, Soil Sci. Soc. Am. J., 64, 1272-1284, 2000 . von der Heyden, C. J.: The hydrology and hydrogeology of dambos: a review, Prog. Phys. Geog., 28, 544-564, 2004.

Wan, C., Yilmaz, I., and Sosebee, R. E.: Seasonal soil-water availability influences snakeweed root dynamics, J. Arid Environ., 51, 255-264, 2002.

Weiler, M. and McDonnell, J. J.: Virtual experiments: a new approach for improving process conceptualization in hillslope hydrology, J. Hydrol., 285, 3-18, 2004.

Weiss, M., Baret, F., Smith, G. J., Jonckheere, I., and Coppin, P.: Review of methods for in situ leaf area index (LAI) determination: Part II. Estimation of LAI, errors and sampling, Agr. Forest Meteorol., 121, 37-53, 2004.

White, W. N.: A Method of Estimating Ground-water Supplies Based on Discharge by Plants and Evaporation from Soil-Results of Investigations in Escalante Valley, Utah, USGS Numbered Series, 659-A, U.S. Department of the Interior, Geological Survey, 105 pp., 1932.

Xu, K., Daïan, J.-F., and Quenard, D.: Multiscale structures to describe porous media Part I: Theoretical background and invasion by fluids, Transport Porous Med., 26, 51-73, 1997a.

Xu, K., Daïan, J.-F., and Quenard, D.: Multiscale structures to describe porous media Part II: Transport properties and application to test materials, Transport Porous Med., 26, 319-338, 1997b. 